\title{
The World Bank and the Creation of the International Center for Settlement of Investment Disputes: Legality and Legitimacy
}

\author{
Wenwen Liang *
}

\begin{abstract}
This chapter is not intended to challenge the legitimacy of the role played by the World Bank in the establishment of the International Centre for Settlement of Investment Disputes (ICSID). Instead, the purpose is to identify and look into the key legality and legitimacy concerns about ICSID's establishment from an international law perspective, taking into consideration the evolving legality and legitimacy discourses over the last decades. In particular, it examines the features and background of ICSID's creation, the role of the World Bank therein, the legal basis of such a role under international institutional law and the law of treaties, and the procedures employed by the World Bank in its formulation of the ICsID Convention. This chapter sheds some light on how similar initiatives of international organizations may be undertaken to comply with legality and legitimacy requirements, in order to better recommend themselves to member States.
\end{abstract}

\section{Introduction}

The International Center for Settlement of Investment Disputes (ICSID) has long been a leading institution for the resolution of investment disputes between private investors and host States, and for the development of international investment law. The World Bank ${ }^{1}$ played a significant role in the establishment of ICSID, when arbitration between private parties and States was rather novel and disputed, and States' positions on compensation for expropriation of investment were extremely divided. ICSID's creation was particularly

* Wenwen Liang, Associate Professor, Luojia Young Scholar, Wuhan University Law School, Wuhan University Institute of International Law, China. Principle research area, international financial law. PhD in Law, The University of Manchester, wenwen.liang@whu.edu.cn.

1 For the purpose of this chapter, the World Bank refers to the International Bank for Reconstruction and Development (IBRD).

(C) ASIAN INFRASTRUCTURE INVESTMENT BANK (AIIB), 2019 | DOI:10.1163/9789004407411_009 
challenging and demanding in the context of the prevalent nationalization of private foreign investments from developed countries by host developing States, increasing calls for protection of foreign private investments, and the fierce confrontation between host developing States and capital exporting developed ones. $^{2}$

After repeated setbacks to establish substantive investment protection standards by various international organizations, such as the Organization for Economic Co-operation and Development Draft Convention on the Protection of Foreign Property which was not adopted, and the United Nations Declaration on Permanent Sovereignty over Natural Resources which failed to satisfy expectations to enhance protection of foreign investments in host States, ${ }^{3}$ the World Bank facilitated the establishment of ICSID as a forum for the voluntary settlement of investment disputes through conciliation or arbitration proceedings between the host State and the foreign investors on an equal footing, without the intervention of the investor's national State. ${ }^{4}$ It was innovative since dispute resolution was either between both State parties under public international law or between private parties under national law. The ICSID Convention (Convention) firmly establishes the capacity of a private individual or corporation to start judicial proceedings against a State in an international forum. ${ }^{5}$ It was radical under international law as participation is voluntary and after voluntary participation, members may opt to give consent to ICSID's jurisdiction in respect of particular disputes. ${ }^{6} \mathrm{~A}$ member of ICSID is obliged to enforce the award once the consent to jurisdiction is given. ICSID has also developed abundant case law on substantive standards for the appropriate protection of international investments.

ICSID's creation was basically sponsored by the World Bank whose Executive Directors formulated the text of the Convention based on the preparatory work by World Bank staff. However, due partly to this international financial institution's lack of explicit judicial authority for resolving investment disputes between private investors and host States, doubts and challenges to ICsID's legitimacy have persisted — the so-called legitimacy crisis—including ICSID's intervention in State sovereignty and the power of arbitrators to adjudicate State regulation. How the very idea of ICSID's creation survived the legal challenges and obstacles, and the legal techniques employed to have it finally established with legality and legitimacy deserves careful analysis under international law.

\footnotetext{
2 See Shawcross 1961.

3 Baltag 2016, 4.

4 Broches 1972, 343 .

5 Ibid, 349 .

6 Ibid, 348.
} 
In this chapter, legality refers to lawfulness and conformity with international law. ${ }^{7}$ International organizations as subjects of international law are bound by their respective constitutions and international agreements to which they are parties, and general international law. ${ }^{8}$ The applicable rules of general international law are not easy to identify precisely. ${ }^{9}$ Due to the uncertainty in the law applicable to the acts of an international organization, sometimes mere legality may not be sufficient to shelter such acts from potential challenges, whether from the member States or non-member States of an organization or other affected parties.

Legitimacy serves as the further justification of an act of an international organization besides legality. Legitimacy refers to the justification of public power to take binding decisions ${ }^{10}$ with diverse meanings. Generally, legitimacy may lie in the source, procedure or results of an act or a power. ${ }^{11} \mathrm{~A}$ common view is that legitimacy of international law resembles the democratic legitimacy of national governance, ${ }^{12}$ given the transfer of certain regulatory powers from sovereign States to international organizations. ${ }^{13}$ Legitimacy may refer to the following. Firstly, State consent forms the basis of the whole international law system and naturally legitimizes an act of an international organization. ${ }^{14}$ Second, procedures similar to due process and democratic fundamentals would largely legitimize an act of an international organization. ${ }^{15}$ Third, the outcome of an act serves to legitimize the act, which is controversial. ${ }^{16}$ Legitimacy in this chapter refers to the first two factors: State consent and appropriate democratic procedures. The importance of representation and decision-making for the purpose of procedural legitimacy is widely acknowledged. ${ }^{17}$ A customary process that gives effect to State consent tends to be legitimate, otherwise its legitimacy is likely to be challenged. ${ }^{18}$

Due to the uncertain and mostly optional nature of the applicable rules of international law, it may be difficult to distinguish legality from legitimacy occasionally. As such, discussions may combine the two where necessary.

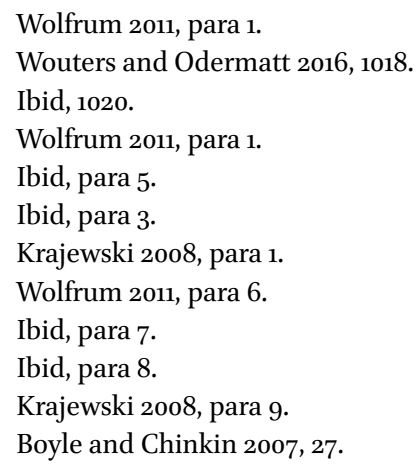


Following this introduction, two further sections address a pair of resultant issues. The first is whether it falls within the World Bank's competence to facilitate the establishment of ICSID, under applicable legal rules, in particular, the Articles of Agreement of the World Bank (Articles). This involves the powers of international institutions under international law as well as the interpretation of the constituent treaties of international institutions under the law of treaties; and whether the appropriate internal organ may determine the authority of the World Bank to facilitate the creation of ICSID under applicable rules. The second question is whether the proceedings leading to the creation of ICSID comply with the requirement of legality and legitimacy, including specifically whether the proceedings leading to the creation of ICSID followed applicable rules under international law and comply with legitimacy discourses. The chapter then offers some conclusions.

During the discussions of the initiative to establish ICSID, an essential issue repeatedly raised was the potential inconsistency between the World Bank's claimed power to deal with a proposal for the Convention and the purposes and provisions of its Articles. ${ }^{19}$ In response, the World Bank justified its initiative on two grounds: (i) a purposive interpretation of its Articles, in particular its mandate to promote private investment and development, and (ii) the practice of the World Bank in facilitating dispute resolution between private investors and member countries, as reflected in, inter alia, regional consultation meetings organized by its General Counsel.

\subsection{Implied Power: The World Bank's Position}

The World Bank argues that a proper interpretation of the purpose of the institution to promote private investment and promote development, as laid down in its Articles of Agreement (Article I(ii)), leads to the conclusion that establishing a body for resolving investment disputes between private investors and host States serves that purpose and thus, is within its competence.

The fact that the World Bank had taken the initiative in promoting an international agreement in a field which might not be regarded as falling directly within its sphere of activity was due to the fact that the World Bank was not merely a financing mechanism but, above all, a development institution. While its activities did consist in large part of the provision of finance, much of its

19 ICSID, 'Meeting Memorandum, SecM 62-68', 10 April 1962, para 18. 
energy and resources were devoted to technical assistance and advice directed toward the promotion of conditions conducive to rapid economic growth and the creation of a favorable investment climate in the broadest sense of the term. To that end, sound technical and administrative foundations were essential, but no less indispensable was the firm establishment of the rule of law. ${ }^{20}$

The World Bank has long held that its powers are not limited to those in the Articles. Rather, it is possessed of implied powers to undertake any action to further its objectives, subject to the requirement that such powers do not contravene its Articles. ${ }^{21}$ Most relevant here is the prohibition of intervention in the political affairs of member countries in Article IV(10) of the Articles, which provides that 'the [World] Bank and its officers shall not interfere in the political affairs of any member; nor shall they be influenced in their decisions by the political character of the member or members concerned. Only economic considerations shall be relevant to their decisions'. It is admitted that the prohibitions of the World Bank's interference in the political affairs of its members cannot be interpreted as if they did not exist. Given in part the fact that economic and political considerations are often intertwined, ${ }^{22}$ the World Bank has expanded its activities to promoting environmental protection, sustainable development, human rights and good governance, by the teleological interpretation of its Articles guided by the implied power doctrine. ${ }^{23}$

\subsection{Implied Power: Public International Law}

The World Bank's interpretation of its Articles adopts the implied power or functional approach which recognizes that international organizations have implied powers to undertake any other actions to further its objectives. The implied power approach is widely recognized in general international law and treaty law, including the Vienna Convention on the Law of Treaties (1969) (VCLt (1969)), and the, Vienna Convention on the Law of Treaties between States and International Organizations or between International Organizations (1986, and not yet in force) (VCLT (1986)), and the jurisprudence of various international tribunals.

The approach to the interpretation of constituent treaties of international institutions under the law of treaties is famously flexible. Constituent instruments are a special category of treaties creating an entity with legal personality and autonomy. As the International Court of Justice (ICJ) held, 'the

\footnotetext{
20 ICSID, 'Summary Record of Proceedings, Z 7', 30 April 1964, 240.

21 Parra 2012, 29.

22 Shihata, 'Dynamic Evolution' 2000, 241.

23 See ibid.
} 
constituent instruments of international organizations are also treaties of a particular type; their object is to create new subjects of law endowed with a certain autonomy, to which the parties entrust the task of realizing common goals. ${ }^{24}$ Despite the dynamic and autonomous aspect of constituent treaties of international institutions, it is widely acknowledged that the approach to interpretation (of constituent treaties) is within the general Vienna Convention framework, ${ }^{25}$ with certain flexibilities. ${ }^{26}$ First, VCLT (1969) is residual in character in the sense that States or intergovernmental organizations remain free to agree upon their own rules in a particular treaty. ${ }^{27}$ Second, Article 31 of VCLT (1969) on treaty interpretation adopting the teleological method and the notion of effectiveness ${ }^{28}$ is broad and flexible. Third, both VCLT (1969) and VCLT (1986) allow additional means of interpretation in their respective Article 5, which provides that the Convention applies to any treaty which is the constituent instrument of an international organization and to any treaty adopted within an international organization without prejudice to any relevant rules of the organization. Thus, broad deference in interpretation is shown to the rules and practices of international organizations.

Articles 31 of VCLT (1969) summarizes the confused practices of the ICJ and the Permanent Court of International Justice (PCIJ) prior to the 1950s, which embody the teleological method and the notion of effectiveness. ${ }^{29}$ Interpretative methods diversified without much coherence. ${ }^{30}$ Practices of the ICJ and the PCIJ relied on the text as an authentic expression of the parties' will, the parties' subjective intentions which are distinct from the text as well as the purpose and object of the treaty, with no clear dividing line. ${ }^{31}$ Such approaches were adopted in Article $3^{1}$ (1) of VCLT (1969) providing that 'a treaty shall be interpreted in good faith in accordance with the ordinary meaning to be given to the terms of the treaty in their context and in the light of its object and purpose'.

Thus, interpretation practice by competent entities flowing from the amorphous Article 31 of VCLT (1969) conforms to the letter and spirit despite divergent results. Article 31 of VCLT (1969) contributed to the doctrines of implied powers and of effectiveness in international law. It is often claimed that an

\footnotetext{
24 ICJ, Nuclear Weapons 1996, 75.

25 Brölmann 2012, 508.

26 Ibid, 509 .

27 Anderson 2011, para 29.

28 Sorel and Eveno 2011, para 4.

29 Ibid, para 4.

$30 \quad$ Ibid, para 6.

31 Ibid, para 11
} 
organization has implied powers necessary to function effectively or achieve its purposes like express powers in its constituent document, and implied powers are deemed to derive from the intentions of the organization's founders. $^{32}$ In the ICJ's Advisory Opinion, Reparation for Injuries, ${ }^{33}$ the doctrine of effectiveness establishes a presumption that an action by an international organization for performing its purpose is valid. The presumption has been repeatedly affirmed. For example, in Certain Expenses, the ICJ concludes that: '... when the Organization takes action appropriate for the fulfilment of one of the stated purposes of the United Nations, the presumption is that such action is not ultra vires the Organization.' ${ }^{34}$

It is widely recognized that the doctrines of implied powers and of effectiveness tend to amplify the powers of the international organizations. ${ }^{35} \mathrm{~A}$ comprehensive study of the case law of international tribunals shows that such tribunals tend to interpret liberally the objectives of the organization and thus recognize extensive powers of the organization. ${ }^{36}$ International organizations, when interpreting their constituent instruments, also tend to interpret liberally the powers specified in their constitutional instruments. For example, the United Nations Security Council (UNSC) justifies establishing the International Criminal Tribunal for the former Yugoslavia (ICTY) as an instrument for its principal function of maintaining international peace and security as stipulated in the United Nations Charter, even though no judicial function is expressly attributed to it for such a purpose. ${ }^{37}$

\subsection{Subsequent Practices of Member States and the World Bank: The World Bank's Position}

The second justification provided by the World Bank is the World Bank's facilitation of resolution of investment disputes between private investors and host States, at the request of States. As noted by staff of the World Bank:

It had on a number of occasions been approached by governments and foreign investors who had sought its assistance in settling investment disputes and had been encouraged to bend its efforts in that direction by such events as the enactment by Ghana of foreign investment legislation which contemplated the settlement of certain investment disputes

\footnotetext{
$32 \quad$ Klabbers 2016, 148.

33 ICJ, Reparation of Injuries 1949, 182.

34 ICJ, Certain Expenses 1962, 168.

35 Röben 2010, para 40.

36 Blokker 2016, 955 .

37 ICTY, Tadić 1995; Scheffer 2016, 284-87.
} 
'through the agency of' the World Bank. Similarly, Morocco and a group of French investors had entrusted to the President of the Bank the appointment of the President of an arbitral tribunal to settle disputes under a series of long-term contracts. ${ }^{38}$

The World Bank argued that States' request for it to help resolve disputes and the involvement of the World Bank justify the establishment of such a judicial body. State practices granting the power in relation to dispute resolution to the World Bank can indeed enhance the implied power of the World Bank to promote private investment. However, there is uncertainty whether occasional requests by States to the World Bank to facilitate the resolution of investment disputes can be equivalent to the creation of a regular judicial body of investment dispute resolution. Assuming there is no strictly prior State practice of authorizing the World Bank to create a judicial body for resolving investment disputes, there is a question of whether practices of an international organization may be relevant. This question is a matter of interpretation of constituent treaties of international organizations.

\subsection{Subsequent Practices under Public International Law}

Subsequent practices are recognized as grounds for interpretation of treaties under Article 31(3)(b) of VCLT (1969), which provides that any subsequent practice in the application of a treaty which establishes the agreement of the parties regarding its interpretation shall be taken into account, together with the context, for the purposes of interpretation. This position has been acknowledged in the work of the International Law Commission (ILC) and jurisprudence of international courts and tribunals. For constituent treaties of international organizations, subsequent practices regarding such treaties raise particular issues of deciding whether the practices of States or the organization itself count. Subsequent practice of States indicates State intention which serves as the basis of treaties, while subsequent practices of an international organization may not necessarily amount to the intention of States members themselves, ${ }^{39}$ unless there is an established agreement of the States parties. However, Article 5 of VCLT (1969) allows the established practice of the organization as falling within the rules of the organization, ${ }^{40}$ as reinforced by Article 2 (1) (j) of VCLT (1986).

38 ICSID, 'Summary Record of Proceedings, Z 7', 30 April 1964, 240.

39 Gardiner 2015, 280.

$40 \quad$ Ibid, 281. 
Case law has shown divergence on this point. In Legality of the Use by a State of Nuclear Weapons in Armed Conflict, the ICJ indicated a rationale for treating resolutions of an organization as relevant practice if they establish agreement of the members of the organization, which is in line with the provision on subsequent practice in the Vienna rules. In the Advisory Opinion on the Wall in Occupied Palestinian Territory, the ICJ considered the practice of the General Assembly and Security Council of the United Nations without investigating whether the practice established agreement of all member States. ${ }^{41}$ There has been no precise requirement for using subsequent practices in the interpretation of constitutive treaties. ${ }^{42}$

The latest ILC work on subsequent practice recognizes that subsequent practice of the parties may arise from or be expressed in the practice of an international organization in the application of its constituent instrument, ${ }^{43}$ and practice of an international organization in the application of its constituent instrument may contribute to the interpretation of that instrument. ${ }^{44}$ The ILC emphasizes that the practice of an international organization can only be relevant for the interpretation of its constituent instrument if that organization has acted within its competence. ${ }^{45}$ The requirement of acting within its competence again is subject to the consent of member States of the organization.

Thus, the precise meaning of subsequent practice of State Members to an international organization or as the subsequent practice of the organization for the purpose of interpreting the constituent instrument of the organization is uncertain. Due to this uncertainty, the World Bank's reliance on States' practices to facilitate the creation of a judicial body such as ICSID raises no serious challenges to legality and legitimacy under international law.

\subsection{The World Bank's Power to Interpret Its Articles of Agreement}

The World Bank staff who assisted in the drafting of the Convention, including the President and the General Counsel of the World Bank, addressed the power to facilitate the creation of ICSID and the interpretation of its Articles of Agreement, as cited above, in speeches in regional consultative meetings, ${ }^{46}$ and in responses to specific enquiries from States during its drafting process, but not in any formal documents.

\footnotetext{
41 Ibid, 283.

42 Ibid, 284.

43 ILC, 'Draft Conclusions on Subsequent Agreements and Subsequent Practice' 2018, conclusion $12(2)$.

44 Ibid, conclusion 12(3).

45 Ibid, conclusion 12, commentary para 36.

46 ICSID, 'Summary Record of Proceedings, Z 7', 30 April 1964.
} 
Article IX (a) of the Articles provides that any question of interpretation of the provisions of the Articles between any member and the Bank or between any members of the Bank shall be submitted to the Executive Directors for their decision, and Article Ix (b) of the Articles provides that the Executive Directors' decision is subject to appeal by a member to the final decision of the Board of Governors. Formal interpretation by the Executive Directors has been used several times before 1964. Since 1964, only one formal decision on the interpretation of the Articles has been taken on the valuation of the World Bank's capital after the demise of the gold standard. The Executive Directors' discussions often concurred with the legal opinion by the General Counsel. ${ }^{47}$

The lack of formal interpretations, for example on the power of the World Bank to prepare and facilitate the creation of ICSID, may be justified by State consent to the World Bank exercise of such power. If there were challenges to the legality of the World Bank's power to facilitate the creation of ICSID, its Executive Directors would have given a formal interpretation which would have been most likely approved by the Board of Governors on appeal. It can be seen that the World Bank lacks such checks and balances which are common in democratic States ${ }^{48}$ but uncommon in most international organizations ${ }^{49}$ although the World Bank has shown increasing sensitivity to transparency.50

\subsection{Conclusion}

The World Bank relied on the teleological interpretation of its Articles, in light of the implied power doctrine and its practice of helping resolve investment disputes, to justify its role in the facilitation of the creation of ICSID. This is largely consistent with the then evolving doctrines and practices of the law of treaties. The World Bank's internal interpretation of its Articles again reflects a customary practice amongst international organizations. The extensive power of liberal interpretation of its power specified in the Articles largely conforms with legality as required under the liberal and vague rules of international law. Similar approaches nowadays may raise legitimacy concerns under current discourses where State consent is considered absent.

47 Shihata, 'Dynamic Evolution' 2000, 224-25; Schlemmer-Schulte 2014, para 21.

48 Schlemmer-Schulte 2014, para 99.

49 See Wouters and Odermatt 2016, 1018.

5o For example by publishing formal decisions on interpretation, inter alia,see SchlemmerSchulte 2014, para 103. 


\section{Proceedings Leading to the ICSID Convention}

The desirability and practicability of establishing institutional facilities, sponsored by the World Bank, for the settlement through conciliation and arbitration of investment disputes between States and foreign investors was submitted to the Board of Governors of the World Bank at its Annual Meeting in 1962. At that Meeting, the Board of Governors adopted a resolution authorizing the Executive Directors to study the question. ${ }^{51}$ After informal discussions on the basis of working papers prepared by World Bank staff, the Executive Directors convened consultative meetings of legal experts designated by member governments. The meetings were attended by legal experts from 86 countries.

The four consultative meetings laid down the basis for a Preliminary Draft prepared by the staff of the World Bank..$^{52}$ The Executive Directors reported to the Board of Governors at its Annual Meeting in 1964 that it would be desirable to establish the institutional facilities by an intergovernmental agreement. The Board of Governors adopted a resolution, authorizing the Executive Directors to formulate the Convention. With a view to achieving a text with the largest possible acceptance amongst members, ${ }^{53}$ the World Bank invited its members to designate representatives to a Legal Committee to assist the Executive Directors. This Committee met in Washington D.C in 1964, with the representatives of the 61 member countries. ${ }^{54}$

The Executive Directors took the final action on the text of the Convention in 1965 and the Convention entered into force in 1966.55 The Contracting States include most capital exporting countries and some capital importing countries. ${ }^{56}$

\subsection{Features of the Preparation Proceedings}

The preparation proceedings outlined above exhibited several noteworthy dynamics, namely (i) the preference for a separate legal convention rather than a resolution of a governing organ of the World Bank, (ii) the work of the Executive Directors of the World Bank, rather than a separate diplomatic conference, in preparing the Convention and (iii) concerns to achieve as broad-based representation as possible. These features are examined in detail, below.

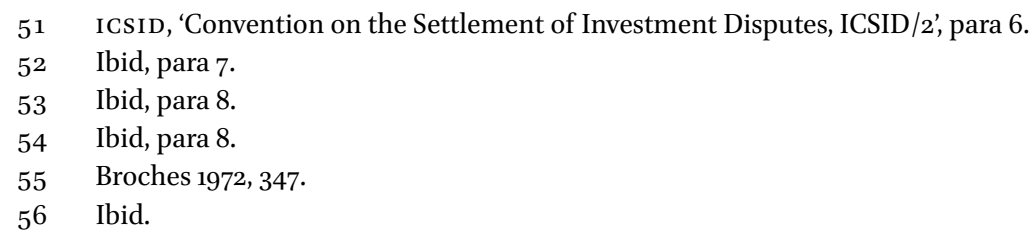


ICSID was established by a Convention rather than a mere resolution of the World Bank. A convention, as a treaty, is binding on contracting States. A resolution will depend for its effect on the constituent instrument of the issuing international organization. No binding force could be obtained by a resolution of the World Bank's Board of Executive Directors in this regard, unless accepted by States. It was submitted that a mere resolution of the World Bank would suffice to create a dispute resolution body on a voluntary basis, but this is not sufficient to establish State consent to arbitrate and comply with the arbitral awards as binding obligations under international law. ${ }^{57}$

Creating an international body with a resolution by an international organization is unusual since a mere resolution cannot, in principle, bind Member States. An example of creating an international body with a resolution is the establishment of the ICTY by the UNSC. The UNSC adopted a resolution to create the ICTY as a nonmilitary measure to maintain and enforce international peace and security. The United Nations Secretariat drafted the Statute of the ICTY. Even for the UNSC with the unique enforcement power for international peace and security, its resolution to create ICTY was challenged on the grounds of legitimacy, due to the lack of State consent and the expansive interpretation of the enforcement power to include creating a tribunal. ${ }^{58}$ For organizations without such enforcement powers, creating an international organization simply by a resolution would not be binding on member States unless State consent is obtained.

The World Bank rightly decided to propose a Convention rather than a mere resolution, in order to create binding obligations on States bound by the Convention on a sphere not directly within the World Bank's powers. However, a convention comes with disadvantages, such as the delays of diplomatic conferences to discuss and adopt the draft, which were carefully avoided by the World Bank.

\subsubsection{Executive Directors' Preparation of the Convention}

The usual way of preparing an intergovernmental agreement is by a diplomatic or inter-governmental conference convened for the purpose. ${ }^{59}$ The World Bank considered that a diplomatic conference might unnecessarily delay and impede progress. ${ }^{60}$ The method adopted by the World Bank was to prepare, 
negotiate and formulate the Convention and submit it to governments, which was unorthodox ${ }^{61}$ and sui generis. ${ }^{62}$ The World Bank staff prepared working papers and drafted text for the consideration of the Executive Directors. ${ }^{63}$ The Executive Directors finalized and adopted the text and accompanying report. ${ }^{64}$ The Executive Directors then submitted to governments, not for further discussion but for States to decide whether to join the Convention or not. The final decision was taken within the World Bank rather than at a separate intergovernmental conference. ${ }^{65}$ There was indeed the proposition during the process that the Executive Directors should do no more than prepare a draft as the basis of discussion and differences in governmental views should be aired in direct confrontation in diplomatic conferences, regarding a subject matter outside the particular expertise of the Executive Directors. ${ }^{66}$

The central point in treaty making is to ensure the expression of State intentions and reach decisions consented to by States under basic democratic requirements. Treaty making via international conferences is a custom but is not mandatory. Diplomatic conferences convened for the purpose of concluding a multilateral treaty mainly follow parliamentary practices which ensure procedural legitimacy. States can decide rules of procedure for a diplomatic conference. ${ }^{67}$ The World Bank's adoption of the text of a convention among its Executive Directors rather than by a diplomatic conference would be legal and legitimate if the principle of State consent and democratic process may be guaranteed.

\subsubsection{Representation, Voting and Consensus}

The World Bank recognized that drafting the ICSID Convention by its Executive Directors could cause a potential lack of representation of member States and lead to an inability to fully air views by those States. Since the Executive Directors (2o in number) did not express the principle of sovereign equality (member States totaled around 100 in number at the time), ${ }^{68}$ the World Bank achieved wider representation of member States by organizing the regional consultative meetings and by the Legal Committee. ${ }^{69}$ The regional consultative

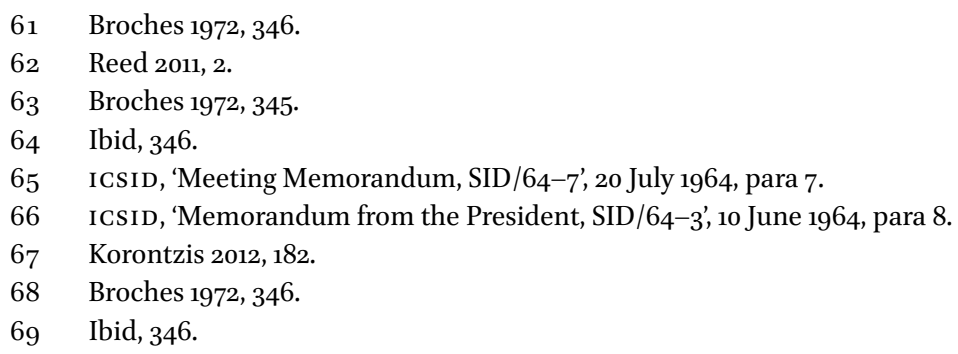


meetings had legal experts from 86 States..$^{70}$ The Legal Committee had representatives from 61 member States. ${ }^{71}$

Closely related to representation in the drafting process are the decisionmaking rules. ${ }^{72}$ The World Bank's Articles provide weighted voting on the basis of financial contributions by member States. ${ }^{73}$ If the Executive Directors adopted weighted voting, the draft Convention may not be welcome to States with minor voting shares. ${ }^{74}$ The Executive Directors could have adopted the weighted voting to adopt the Convention against objecting States. ${ }^{75}$ However to ensure broad acceptance amongst member States, the Executive Directors sought a consensus in informal meetings and also in the Legal Committee. ${ }^{76}$ Article 4 (f) of the Rules for the Conduct of Proceedings of Legal Committee provides 'a consensus shall be deemed to have been reached if, at the end of the discussion, no member present raises any objection. ${ }^{77}$ Consensus is a procedure for adopting a decision without a formal vote when there are no formal objections, not necessarily universal acceptance. ${ }^{78}$ Consensus is effective in decision making, ${ }^{79}$ although consensus may mask opposition or become the object of subsequent objection or non-participation. ${ }^{80}$ The draft ICSID Convention adopted by consensus did not conceal the opposition of Latin American countries who did not join the Convention until years after the adoption of the Convention. ${ }^{81}$ Consensus in its adoption does not necessarily detract from the legitimacy of the ICsID Convention since the dissidents can denounce the Convention. Some Latin American countries have now denounced the ICSID Convention. For example, Bolivia in 2007 and Ecuador in 2010 formally withdrew from ICSID. ${ }^{82}$

Under international law, decision making rules are optional and flexible, subject to basic legitimacy requirements of democratic procedures. For example, decision making rules in diplomatic conferences for drafting treaties are flexible and it is up to States participating in such conferences to determine

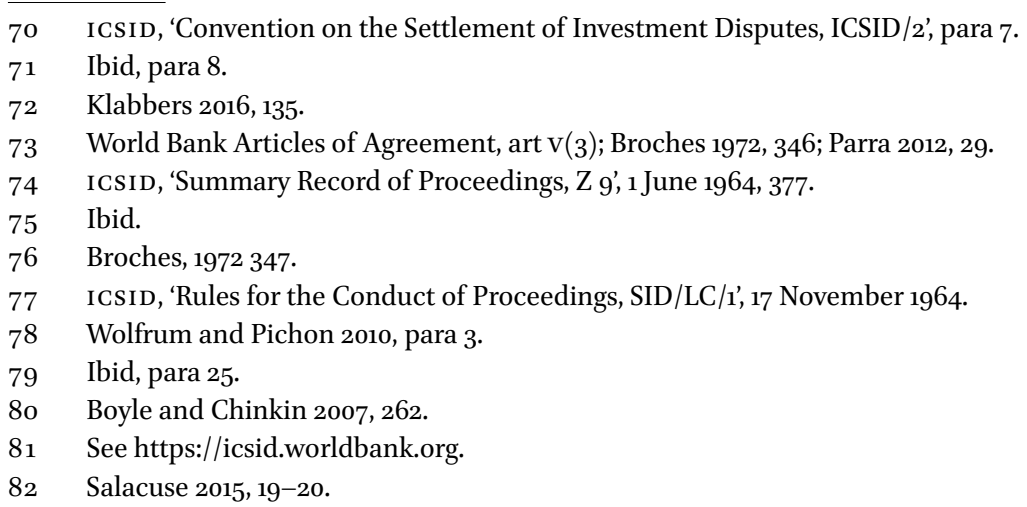


such procedures. Article 9 of VCLT 1969 provides for two options for the adoption of the text of a treaty, namely by the consent of all participating or by majority voting. Conferences apply different majorities or consensus. ${ }^{83}$ The recent trend in diplomatic conferences is to seek the widest possible consensus during the treaty-making process. ${ }^{84}$

The World Bank enhanced the representation of member States by organizing the regional consultative meetings and by the Legal Committee. The World Bank's adoption of the consensus approach in the Legal Committee for the drafting of the ICSID Convention mirrors the practice in diplomatic conferences for treaty making and enhances the airing of views of participating States in the drafting process chaired by the Executive Directors. The proceedings leading to the adoption of the ICSID Convention provide comfort to the general rules of international law and doctrines of procedural legitimacy.

\subsection{Conclusion}

ICSID's creation by a convention rather than by an internal resolution of the World Bank creates binding obligations on contracting States. The unusual way of drafting the ICSID Convention by the Executive Directors of the World Bank enhanced procedural legitimacy by ensuring proper representation of member States in regional consultative meetings and in the Legal Committee and adopting the consensus procedure in the Legal Committee composed of State legal officials. ICSID's creation is consistent with international law on treaty making which affords a certain level of flexibility in the pursuit of democratic due process.

\section{Conclusion}

In conclusion, ICSID's establishment enjoys legality and legitimacy under general international law. The power of the World Bank to prepare the creation of a judicial institution is rooted in its Articles under a functional interpretation and the doctrine of implied power, namely to promote private investment, sufficient to authorize the facilitation of the creation of ICSID for resolving investment disputes. Such an approach has been adopted extensively amongst international organizations under international law and in particular, the law of treaties. The World Bank's power to interpret its Articles is expressly

$83 \quad$ Korontzis 2012, 188.

84 Ibid, 184. 
provided in its constituent treaty which is also widely seen in the constituent instruments of other international organizations.

Specific practice adopted to create ICSID by a convention rather than by an internal resolution of the World Bank has reinforced the legality and legitimacy of the establishment of ICSID. The adoption of the text of the ICSID Convention by the World Bank's Executive Directors supported by regional consultative meetings and Legal Committee meetings, rather than by a diplomatic conference, achieved effectiveness and efficiency in decision making, at no significant cost of legality and legitimacy.

The legality and legitimacy of international organizations has been scarcely been tested so far. However, with the growing powers of international organizations under the implied powers doctrine and the burgeoning global governance discourses, more checks and balances similar to those in national democracies may be expected in order to safeguard the central position of State consent in international law and democratic procedures, as well as to restore a balance of powers between international organizations and sovereign States. ${ }^{85}$

\section{Reference list}

Anderson D H, 'Art.5 1969 Vienna Convention' in Olivier Corten and Pierre Klein (eds), The Vienna Conventions on the Law of Treaties (OUP 2011).

Baltag C, 'The ICSID Convention: A Successful Story-The Origins and History of the ICSID' in Crina Baltag (ed), ICSID Convention after $5^{\circ}$ Years: Unsettled Issues (Kluwer Law International 2016).

Blokker N, 'Constituent Instruments' in Jacob Katz Cogan, Ian Hurd and Ian Johnstone (eds), The Oxford Handbook of International Organizations (OUP 2016).

Boyle A and Chinkin C, The Making of International Law (OUP 2007).

Broches A, 'The Convention on the Settlement of Investment Disputes between States and Nationals of Other States' (1972) 136 Recueil des cours.

Brölmann C, 'Specialized Rules of Treaty Interpretation: International Organizations' in Duncan B. Hollis (ed), The Oxford Guide to Treaties (OUP 2012).

Certain Expenses of the United Nations (Advisory opinion) [1962] ICJ Rep 151.

D'Aspremont J and De Brabandere E, 'The Complementary Faces of Legitimacy in International Law: The Legitimacy of Origin and The Legitimacy of Exercise' (2011) 34 Fordham International Law Journal 190.

Gardiner R, Treaty Interpretation (OUP 2nd Edition 2015).

85 See d'Aspremont and De Brabandere 2011, 196. 
'IBRD Articles of Agreement' (The World Bank) <www.worldbank.org/en/about/arti cles-of-agreement/ibrd-articles-of-agreement $>$ accessed on 27 February 2019.

ICSID, 'History of the ICSID Convention', (vol ii-1, 1968) < https://icsid.worldbank.org/ en/Documents/resources/History\%20of\%2oICSID\%2oConvention\%20-\%2oVOL UME\%2oII-1.pdf> accessed on 27 February 2019.

ICSID 'History of the ICSID Convention' (vol ii-2, 1968) < https://icsid.worldbank.org/ en/Documents/resources/History\%20of\%2oICSID\%2oConvention\%20-\%2oVOL UME\%20II-2.pdf> accessed on 27 February 2019.

ILC, 'Draft Conclusions on Subsequent Agreements and Subsequent Practice in Relation to the Interpretation of Treaties' (18 May 2018) UN Doc A/CN.4/L.907.

Klabbers J, 'Formal Intergovernmental Organizations' in Jacob Katz Cogan, Ian Hurd and Ian Johnstone (eds), The Oxford Handbook of International Organizations (OUP 2016).

Korontzis G, 'Making the Treaty' in Duncan B. Hollis (ed), The Oxford Guide to Treaties (OUP 2012).

Krajewski M, 'International Organizations or Institutions, Democratic Legitimacy' (Max Planck Encyclopedia of Public International Law 2008) <http://opil.ouplaw .com/view/10.1093/law:epil/978019923169o/law-978019923169o-e495> accessed on 27 February 2019.

Legality of the Use by a State of Nuclear Weapons in Armed Conflict (Advisory opinion) [1996] ICJ Rep 66.

Parra A R, The History of ICSID (OUP 2012).

Prosecutor $v$ Tadić (1995) IT-94-1-AR72.

Reed L, Paulsson J and Blackaby N, Guide to ICSID Arbitration (2nd edn, Kluwer Law International 2011).

Reparation for Injuries Suffered in the Service of the Nations (Advisory Opinion) [1949] ICJ Rep 174.

Röben V, 'International Law, Development through International Organizations, Policies and Practice' (Max Planck Encyclopedia of Public International Law 2010) <http:// opil.ouplaw.com/view/10.1093/law:epil/978019923169o/law-978019923169o-e1426> accessed on 27 February 2019.

Salacuse J W, The Law of Investment Treaties (2nd edn, OUP 2015).

Scheffer D J, 'Criminal Justice' in Jacob Katz Cogan, Ian Hurd and Ian Johnstone (eds), The Oxford Handbook of International Organizations (OUP 2016).

Schlemmer-Schulte S, 'International Bank for Reconstruction and Development (IBRD)', (Max Planck Encyclopedia of Public International Law 2014) <http://opil .ouplaw.com/view/10.1093/law:epil/978019923169o/law-978019923169o-e475?rskey= YktGxt\&result=1\&prd=EPIL $>$ accessed on 27 February 2019.

Shawcross H, 'The Problems of Foreign Investment in International Law' (1961) 102 Recueil des cours. 
Shihata I F I, 'Avoidance and Settlement of Disputes — the World Bank's Approach and Experience' (1999) 1 International Law Forum du droit international 90.

Shihata I F I 'The Dynamic Evolution of International Organizations: The Case of the World Bank' (2000) 2 Journal of the History of International Law 217.

Sorel J and Eveno V B, 'Interpretation of Treaties, Art.31 1969 Vienna Convention' In Olivier Corten and Pierre Klein (eds), The Vienna Conventions on the Law of Treaties (OUP 2011).

Wolfrum R, 'Legitimacy in International Law' (Max Planck Encyclopedia of Public International Law 2011) <http://opil.ouplaw.com/view/10.1093/law:epil/978019923169o/ law-978019923169o-e196o > accessed on 27 February 2019.

Wolfrum R and Pichon J, 'Consensus' (Max Planck Encyclopedia of Public International Law 2010) <http://opil.ouplaw.com/view/10.1093/law:epil/978019923169o/law -978019923169o-e1387> accessed on 27 February 2019.

Wouters J and Odermatt J, 'Assessing the Legality of Decisions' in Jacob Katz Cogan, Ian Hurd and Ian Johnstone (eds), The Oxford Handbook of International Organizations (OUP 2016). 